\title{
EFFECT OF SOME MATERIALS FOR CONTROLLING VARROA MITE ON THE HONEYBEE DRONES (APIS MELLIFERA L.)
}

\author{
SHOUKRY, RASHA S. ${ }^{1}$, A. M. KHATTABY ${ }^{1}$, A. A. EL-SHEAKH ${ }^{1}$, \\ A. H. ABO-GHALIA ${ }^{2}$, and SHEREEN M. ELBANNA ${ }^{2}$ \\ 1. Plant Protection Research Institute, ARC, Dokki, Giza \\ 2. Zool. Dept., Faculty of Sci. (Ismailia), Suez Canal University
}

(Manuscript received 11 November 2012)

\begin{abstract}
The present investigation was carried out to evaluate the effects of different miticides, fluvalinate, Amitraz, oxalic acid, formic acid and thymol on honeybee drones. Drones were measured for body weight, length, width of fore wing and number of sperms in one seminal vesicle. Drones treated with fluvalinate, Amitraz, Oxalic acid and thymol had significantly less weight and less wing length than the control group. The least values of body weight and wing length observed in colonies treated with fluvalinate recorded $0.186 \mathrm{gm}$ and $10.615 \mathrm{~mm}$ respectively, while the highest values of body weight was $0.205 \mathrm{gm}$ and wing length was $10.957 \mathrm{~mm}$ observed with formic acid. Wing width in drones exposed to fluvalinate, Amitraz and oxalic acid were significantly lower than control. Drones exposed to fluvalinate and Ammitraz had significantly lower sperm count than drones of control recorded $4.33 \times 10^{6}$, $3.55 \times 10^{6}$ and $5.39 \times 10^{6}$ respectively. A positive correlation between sperm number and wing size was recorded.

Key words: miticides-drones-Apis mellifera-wing sizesperm number.
\end{abstract}

\section{INTRODUCTION}

Mites that parasitize honeybees have become a global problem that threatens the survival of both managed and feral honeybee colonies, as well as agricultural crops that depend on bee pollination. Tracheal and varroa mites are major contributing factors to the loss of honeybee colonies.

Varroa destructor feed on larval and pupal honeybees as they develop to adult. This feeding causes infested worker bees to have reduced body weight as adults (De Jong et. al., 1982,), sometimes to have deformed wings and abdomens and to have a reduced life span (Ritter et. al., 1984). Drones are about eight times more likely to be parasitized than workers bees (Fuch, 1990) and the effects of parasitism on drones can be devastating. Rinderer et. al., 1998 found that only $59.7 \%$ of drones emerged in $V$. destructor infested colonies. 
Varroa infestation also tended to have negative effects on drone weights mucus gland, seminal vesicle weights and the numbers of spermatozoa. Mating of commercial queens depends upon an ample supply of drones, they must be produced in colonies treated to reduce the numbers of $V$. destructor.

The most common method for mite control are the use of synthetic chemical miticides, as well as natural products, such as organic acids and plant derived oils. Despite the use of these chemicals, colony numbers have continued to decline. In addition, other problems have emerged from the use of miticides in colonies, including the accumulation of chemical residues in bees' wax, as well as mite resistance to the chemicals. Several studies have been conducted showing negative effects of several miticides on colonies' health and individuals in the hives (Rinderer et al. 1999).

The present study aimed to investigate the effect of different miticides used for the control of honeybee mite on the drones with regard to body size and spermatozoa production.

\section{MATERIALS AND METHODS}

The experiment was carried out in the apiary and laboratory of plant protection Research Institute Department (Sharkia branch) to evaluate the effect of some miticides used in controlling varroa destructor on drones honeybee.

\section{(1) Drone rearing}

A total of 18 colonies were used for the experiment, 3 colonies per treatment. Naturally mated sister queens grafted from the same mother were placed in each hive. As queen in colonies laid eggs in drone cells. Colonies had been treated with the used miticides. Two days before drones emergence, drone eggs were held above queen excluders which allowed the collection of all emerged drones.

When drones emerged, they were held in cages made with queen excluder material. The drone cages placed into the hive allowing workers to enter and feed the drones (Collins 2004). Drones remained in the colonies $14-20$ days to allow full sexual maturation.

\section{(2) Treatments}

1- Apistan (10\% fluvalinate) was administrated as one Apistan strip/colony. The strips were inserted vertically between brood combs. The strips removed after 21 days. 
2- Mitac (amitraz $0.2 \%$ ): was treated by applying $10 \mathrm{ml}$ from the solution on cotton pieces placed under the broad combs. The treatment remain for 21 period.

3- Formic acid (60\%): applied by using varroa form where $120 \mathrm{ml}$ formic acid evaporate through carton pieces. The treatment applied for 21 days period.

4- Oxalic acid (5\%): sprayed by $5 \mathrm{ml}$ from the solution on the bees between combs, four times at 4 days intervals.

5- Thymol crystals $(0.75 \mathrm{gm} /$ colony) were kept in a perforated sack to be hung between brood combs. The treatment applied at 10 for 21 days intervals.

\section{(3) Body weight}

Samples of 30 emerged drones from the treated and untreated (control) colonies were weighed individually.

\section{(4) Length and width of wings}

After the drones had been weighed, the fore were dissected in buffered solution $(0.09 \% \mathrm{NaCl})$. The wings were mounted on glass slides using glycerin (Damus and Otis 1997). The length and width of fore wing were measured and recorded with the stereo binocular microscope using a calibrated eye piece micrometer.

\section{(5) Number of spermatozoa}

When drones were at least 14 days, they were considered sexually mature. Eight drones collected from each colony, a total 16 seminal vesicles for each treatment were analyzed as two colonies were used for each treatment. The drones were dissected and one seminal vesicle was removed from each drone. Each seminal vesicle was macerated in $10 \mathrm{ml} 0.5 \%$ saline solution. It was punctured and the spermatozoa dispersed by the sucking and expelling action of a pipette. Total spermatozoa from the one seminal vesicle was estimated using a hemocytometer and light microscope (Rinderer et al 1985).

Data were tabulated and subjected to a statistical analysis and the treatment means were compared by L.S.D. test using Costat Program 1986. 


\section{RESULTS}

\section{(1) The effect of miticides on drones' weight}

The weights of newlyemerged drones treated with miticides are summarized in table (1). The lowest mean drone weight was $0.186 \pm 0.10 \mathrm{gm}$ observed in drones exposed to fluvalinate. There was a significant difference between the mean weights of treated and untreated drones $\mathrm{P}<0.05$.

Weight of drones exposed to fluvalinate, Amitraz, oxalic acid and thymol were significantly lower than the untreated check. Colonies treated with formic acid had no effect on the body weight.

Table. 1. The mean weight, length and width of fore wing of honeybee (Apis mellifera) drones treated with different miticides

\begin{tabular}{|c|c|c|c|c|c|}
\hline \multirow[b]{2}{*}{ Treatments } & \multirow{2}{*}{$\begin{array}{l}\text { Mean drone weight } \\
(\mathrm{gm})\end{array}$} & \multicolumn{4}{|c|}{ Fore wing } \\
\hline & & Length (mm) & $\begin{array}{c}\text { Reduction } \\
\% \\
\end{array}$ & Width (mm) & $\begin{array}{c}\text { Reduction } \\
\quad \% \\
\end{array}$ \\
\hline $\begin{array}{l}\text { Fluvalinate } \\
\text { (Apistan) }\end{array}$ & $0.186 \pm 0.010 b$ & $10.615 \pm 0.260 \mathrm{~d}$ & 5.36 & $3.472 \pm 0.173 b$ & 4.57 \\
\hline Amitraz & $0.186 \pm 0.010 \mathrm{~b}$ & $10.663 \pm 0.262 \mathrm{~cd}$ & 4.93 & $3.556 \pm 0.134 \mathrm{ab}$ & 2.27 \\
\hline Oxalic acid & $0.188 \pm 0.012 b$ & $10.787 \pm 0.200 \mathrm{c}$ & 3.83 & $3.474 \pm 0.168 b$ & 4.52 \\
\hline Formic acid & $0.205 \pm 0.116 a$ & $10.957 \pm 0.155 b$ & 2.31 & $3.647 \pm 0.144 \mathrm{a}$ & - \\
\hline Thymol & $0.192 \pm 0.023 b$ & $10.809 \pm 0.200 c$ & 3.63 & $3.597 \pm 0.115 a$ & 1.16 \\
\hline $\begin{array}{l}\text { Control } \\
\text { (untreated) }\end{array}$ & $0.211 \pm 0.007 \mathrm{a}$ & $11.216 \pm 0.301 \mathrm{a}$ & & $3.639 \pm 0.252 \mathrm{a}$ & \\
\hline$P$ & $0.0000 * * *$ & $0.0000^{* * *}$ & & $0.0016 * *$ & \\
\hline LSD at 0.05 & 0.0072 & 0.1471 & & 0.1066 & \\
\hline
\end{tabular}

\section{(2) The effect of miticides on the length and width of fore wing}

Table (1) showed that the lowest wing length and width were observed in drones exposed to fluvalinate recorded $10.615 \pm 0.260 \mathrm{~mm}$ and $3.472 \pm 0.173 \mathrm{~mm}$ respectively compared with drones reared in the control conditions $11.216 \pm$ $0.301 \mathrm{~mm}$ and $3.639 \pm 0.22 \mathrm{~mm}$.

There was a significant difference between the mean length and width of fore drone wings that treated with different miticides $(P<0.05)$. 
Wing length of drones exposed to fluvalinate, amitraz, formic acid, oxalic acid and thymol during development were significantly lower than that of control. Wing width in drones exposed to fluvalinate, amitraz and oxalic acid were significantly lower than the untreated check. Rearing drones in colonies treated with formic acid or thymol had no significant effect on wing width drones compared with untreated ones.

\section{(3) The effect of miticides on the number of spermatozoa}

Mean sperm number in one seminal vesicle of $5.39 \pm 1.37 \times 10^{6}$ was found for the control drones but the treatments means for fluvalinate, amitraz, oxalic acid, formic acid and thymol were $4.33 \pm 3.03 \times 10^{6}, 3.55 \pm 1.13 \times 10^{6}, 4.70 \pm 1.85 \times 10^{6}, 5.32 \pm$ $1.45 \times 10^{6}$ and $5.02 \pm 1.32 \times 10^{6}$ respectively.

There was a significant difference between sperm numbers in control drones and drones exposed to fluvalinate and Amitraz $(P<0.05)$. Drones exposed to fluvalinate and Amitraz have significant lower sperm counts than those of control, thymol, oxalic acid and formic acid treatments.

Reviewing the obtained results it could be showed, a significant positive correlation between wing length and sperm numbers of different miticides treatments $(p=0.035)$.

The values of mean sperm content in drones treated with different miticides are shown in table (2).

Table. 2. The mean spermatozoa number in one seminal vesicle of sexually mature of honeybee drones of (Apis mellifera ) treated with different miticides.

\begin{tabular}{|l|l|c|}
\hline \multicolumn{1}{|c|}{ Treatments } & \multicolumn{1}{|c|}{$\begin{array}{c}\text { Spermatozoa number/seminal vesicle } \\
( \pm \text { SD })\end{array}$} & $\begin{array}{c}\text { Reduction } \\
\%\end{array}$ \\
\hline Fluvalinate (Apistan) & $4.33 \pm 3.03 \times 10^{6}$ ab & 19.78 \\
\hline Amitraz & $3.55 \pm 1.13 \times 10^{6} \quad \mathrm{~b}$ & 34.26 \\
\hline Oxalic acid & $4.70 \pm 1.85 \times 10^{6} \quad$ a & 12.82 \\
\hline Formic acid & $5.32 \pm 1.45 \times 10^{6} \quad$ a & 1.29 \\
\hline Thymol & $5.02 \pm 1.32 \times 10^{6} \quad$ a & 6.86 \\
\hline Control (untreated) & $5.39 \pm 1.37 \times 10^{6}$ a & \\
\hline P & $0.0151^{*}$ & \\
\hline LSD 0.05 & $1.1346 \times 10^{6}$ & \\
\hline
\end{tabular}




\section{DISCUSSION}

Miticides treatments caused several negative effects on drone bee, including decrease in body weight, wing size and spermatozoal production when compared to drones of control colonies. Exposure to fluvalinate, amitraz, oxalic acid, and thymol during development and maturity caused significant reduction in body weight. Drones in formic acid treated colonies showed no significant differences from control, this finding is in agreement with (Rinderer et al 1998) documented a $5 \%$ reduction in body weight in drones exposed to Apistan, while De Guzman et al 1999 stated that formic acid treatment did not adversely affected drone weight.

Treatment of drones honeybee with different miticides caused reduction in wing length ranged from $5.36 \%$ in drones exposed to fluvalinate, to $2.31 \%$ in drones exposed to formic acid compared with control drones. Also, fluvalinate, amitraz and oxalic acid treatments significantly decreased the wing width of drones honeybee by approximately $4.57 \%, 2.27 \%$ and 4.52 respectively compared to the control .

No significant difference was observed in drones wing width that exposed to formic acid and thymol compared to the control drones. Surviving drones in control colonies had the highest means number of spermatozoa with $5.39 \pm 1.37 \times 10^{6}$ per seminal vesicle or $10.8 \times 10^{6}$ per drone are strongly in agreement with the finding of (Elbassiouny 1992) who recorded $10.62 \times 10^{6}$ spermatozoa on carnelian drones.

Drones in fluvalinate and amitraz treated colonies showed significant differences from control with an average of $4.33 \pm 2.03 \times 10^{6}$ and $3.55 \pm 1.13 \times 10^{6}$ sperm per seminal vesicle respectively. Previous studies have shown that exposure of drones to fluvalinate reduced the amount of sperm found in the seminal vesicles of drones (Fell and Tignor 2001, Rinderer et al 1999). However, (Burley 2007) found that fluvalinate treatment did not adversely affect sperm production.

Our study show no significant decrease in sperm production of drones exposed to formic acid, oxalic acid and thymol compared with spermatozoa number reared in control conditions. In contrast, (De Guzman et a/ 1999) observed that formic acid treatment resulted in surviving drones having a higher average number of spermatozoa than control colonies. Also, (Burley 2007) showed a significant decrease in sperm production of drones exposed to thymol. 


\section{Correlation between wing length and number of spermatozoa}

Wing length used as an indicator for drones size and weight (Berg 1992). The result of our study shows a significant positive correlation of wing length and sperm number in drones treated with fluvalinate, Amitraz, oxalic acid, formic acid and thymol. Schulns et al (2003) observed a significant decrease in spermatozoa production in smaller drones reared in worker cell as opposed to drone sized cells, showing that sperm production in drones depend on body size.

The significant positive correlation of drone body size and sperm number also supported by the fact that Africanized honeybees in South America have significantly lower body weights and at the same time lower sperm numbers than European drones (Rinderer et al, 1985).

In our study we find that exposure of drones to fluvalinate, amitraz, oxalic acid, thymol and formic acid during development and maturity lower the wing length by $5.36 \%, 4.93 \%, 3.83 \%, 3.63 \%$ and $2.31 \%$ respectively compared with control drones, which show a positive correlation with sperm number where, the previous treatment produce $19.78 \%, 34.26 \%, 12.82 \%, 6.86 \%$ and $1.29 \%$ respectively less spermatozoa than control drones.

\section{REFERENCES}

1. Berg, S. 1992. Der Reproduktionserfolg von Drohnen (Apis mellifera L.) unterschiedlicher Größe, Ph.D. Thesis Johann-Wolfgang Goethe Universität Frankfurt am Main.

2. Burley, L.M. 2007. the effects of miticides on the reproductive physiology of honeybee (Apis mellifera L.) queens and drones. M.Sc. Thesis Faculty of Virginia Polytechnic Institute.

3. Collins, A.M. 2004. Sources of variation in the viability of honey bee, Apis mellifera L., semen collected for artificial insemination. Invertebr. Reprod. Dev. 45(3): 231-237.

4. Costat program. 1986. Co Hort software, P.O. Box. 1149, Berkeley CA 94701. U.S.A.

5. .Damus, M.s. and G.W. Otis. 1997. Amorphometric analysis of Apis cerana F. and Apis nigro cincta Smith pollution from south east Asia. Apidologie 28: 209 -223. 
6. De Guzman, L.I., T.E. Rinderer, V.A. Lancaster, G.T. Delatte, and A. Stelzer. 1999. Varroa in the mating yard: III. The effects of formic acid gel formulation on drone production. Am. Bee J. 139(4): 304-307.

7. DEJONG, D., RA. Morse and Gc.Elckwort. 1982. Mite pests of honeybees. Annual Review of Entomology 27: 229 -252.

8. Elbassiouny A.M.M. 1992. Comparative studies on the carniolan honey bee race and its crosses, Ph.D. Thesis, Department of Plant Protection Faculty of Agriculture, Ain Shams University, Cairo, Egypt.

9. Fell, R.D. and K. Tignor. 2001. Miticide effects on the reproductive physiology of queens and drones. Am. Bee J. 141(12): 888-889.

10. Fuch, S. 1990. Preference for drone brood cells by arroa jacobsoni oud in colonies of Apis mellifera carnica. Apidologie 21: 193 -199.

11. Rinderer T.E., Collins A.M. and D. Pesante. 1985. A comparison of Africanized and European drones: weights, mucus gland and seminal vesicle weights, and counts of spermatozoa, Apidologie 16, 407-412.

12. Rinderer, T.E., L.I. De Guzman, V. A. Lancaster, G. T. Delatte and JA. Stelzer. 1998. Varroa in the mating yard: I. The effects of varroa jacobsoni and Apistan on drone honeybees. American Bee Journal 139: 225 -227.

13. Rinderer, T.E., L.I. De Guzman, V.A. Lancaster, G.T. Delatte and J.A. Stelzer. 1999. Varroa in the mating yard: 1 . the effects of Varroa jacobsoni and Apistan on drone honey bees. Am. Bee J.139: 134-139.

14. Ritter, W, E. Leclercq and W. Koch. 1984. Observations des populations d'abeilles et de varroa dans les colonies a different niveauz d'infestation. Apidologie 15: 389 -400.

15. Schluns, H., E. Schluns, J. Van Praagh and R.F.A. Moritz. 2003. Sperm numbers in drone honeybees (Apis mellifera) depend on body size. Apidologie 34: 577584. 


\section{تأثير بعض المواد المستخدمة في مكافحة حلم الفاروا على ذكور نحل العسل}

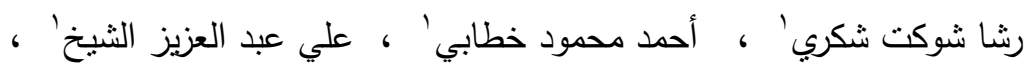

أحمد حسن أبو غالية' ، شيرين محمد محمود البنا؟r

$$
\text { r- - معهز بحوث وقاية النباتات - مركز البحوث الزراعية - الدقي - جيزة }
$$

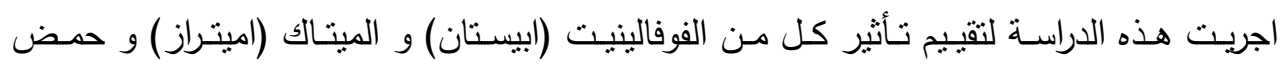

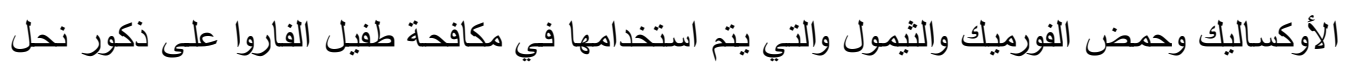

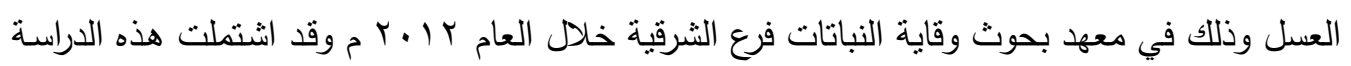

1- بربية ذكور النحل في خلايا يتم معاملتها بالمركبات السابقة.

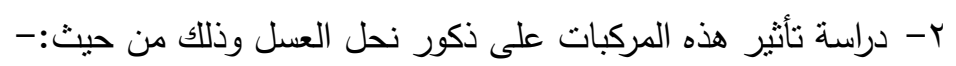

$$
\text { - }
$$

أظهرت الاراسة بعض التأثيرات الناتجة عن استخدام هذه المركبات ويمكن تلخيصها كالأتي:-

1- خفض معنوي في وزن الذكور الناتجة في خلايا تم معاملتها بالفلوفالينيت و الاميتراز وحمض

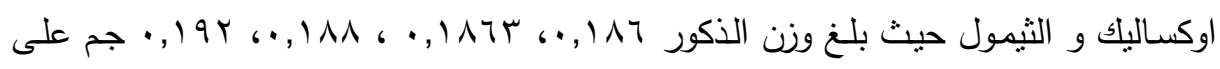

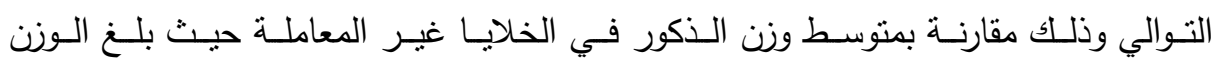
•ج, •

r- خفض في طول وعرض الجناح الأمامي حيث سجل اقل قياس لطول وعرض الجناح الأمامي

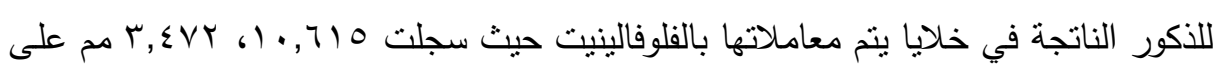

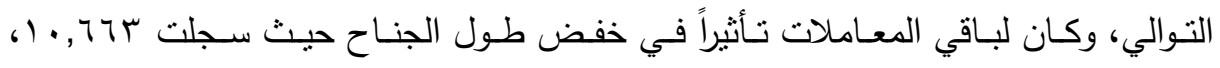

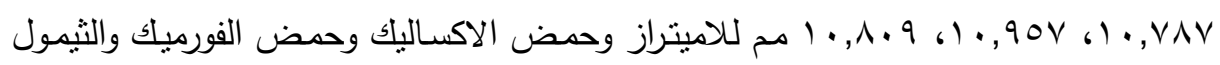

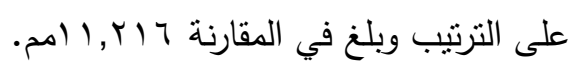
وعلى عرض الجناح حيث سجلت

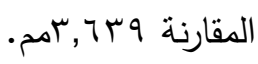

r- انخفاض معنوي في عدد الحيوانات المنوية في الذكور الناتجة في خلايا يتم معاملاتها بكل

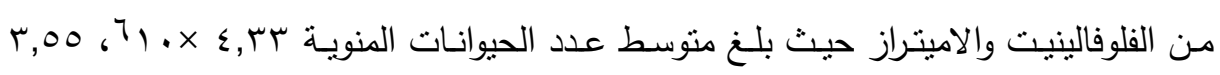


× × آحيوان منوي في الحوصلة المنوية على الترتيب، بينما سجلت باقي المعاملات انخفاضاً

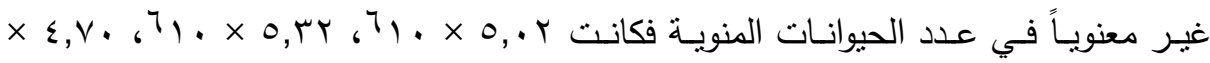
• 17 حيوان منوي لكل من الثيمسل وحمض الفورميك و حمض الاوكسـاليك على التوالي

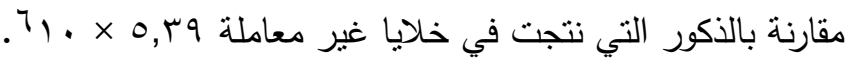

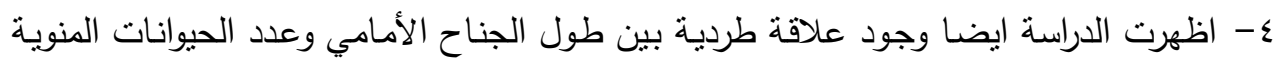

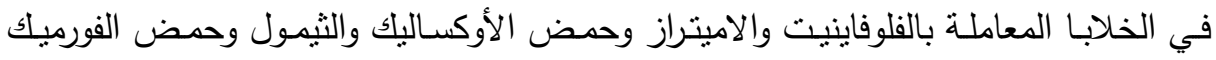

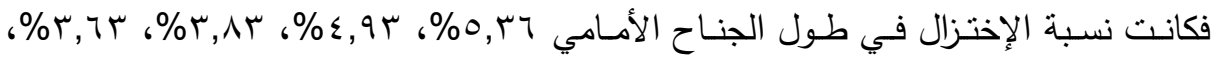

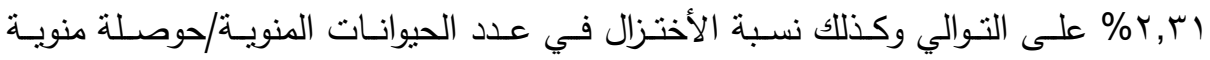

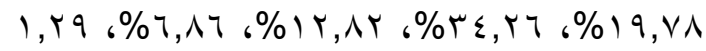
\% على التوالي.

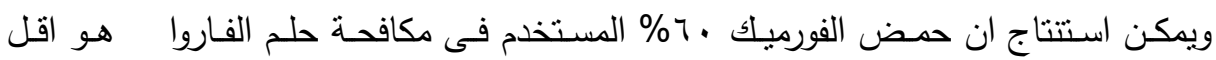
المركبات تاثيرا على ذكور نحل العسل مقارنـة بباقى المركبات التى قللت من مقدرة ذكور النحل على عملية تلقيح الملكات العذارى. 